\title{
1 Reduction of nitrate to nitrite by microbes under oxic conditions
}

2 Constance A. Roco a , Linda Bergaust ${ }^{\mathrm{b}}$, James P. Shapleigh ${ }^{\mathrm{a}}$, Joseph Yavitt ${ }^{\mathrm{c}}$

$4 \quad{ }^{a}$ Department of Microbiology, Cornell University, Ithaca, NY 14853

$5 \quad{ }^{b}$ Department of Chemistry, Biotechnology and Food Sciences, Norwegian University of Life

6 Science, NO-1432, Ás, Norway

$7 \quad{ }^{\mathrm{c}}$ Department of Natural Resources, Cornell University, Ithaca, NY 14853

10 Corresponding author:

11 Joseph B. Yavitt

12 Department of Natural Resources

13 Cornell University

14 Ithaca, NY 14853-3001

15 Phone number: 1-607-255-6601

16 Fax number: 1-607-255-0349

17 E-mail address: jby1@cornell.edu

18

19

20

21 


\section{ABSTRACT}

33 Human activities have greatly increased the input of nitrate to natural and managed ecosystems,

34 but the fate of excess soil nitrate is still unclear. Many studies assume that dissimilatory

35 reduction of nitrate to nitrite is an anaerobic process, but this first step of denitrification can

36 occur in some bacteria at oxygen concentrations that are high enough to repress downstream

37 reduction of nitrite to gaseous products. Here, we examine whether dissimilatory reduction of

38 nitrate under aerobic conditions is an additional, underappreciated fate of nitrate in soil. Aerobic

39 nitrate reduction occurred in soils when provided with both nitrate and a carbon source, with the

40 greatest nitrite accumulation in the wetland sites. The addition of a nitrification inhibitor did not

41 significantly reduce aerobic nitrate reduction activity, nor did an assimilation repressor. Average

42 nitrite production in soils with added carbon, nitrate, and nitrification inhibitor ranged from 7.5-

$4350 \%$ of added N-nitrate in a five-hour incubation. Bacteria capable of aerobic nitrate reduction

44 were readily isolated from these soils, comprising approximately $35 \%$ of the isolates retrieved.

45 Sequencing16S rDNA of these isolates revealed both gram-negative and gram-positive bacteria,

46 with the majority being gram-negative proteobacteria. In six of the isolates, onset of nitrate

47 reduction occurred at $45-86 \%$ of atmospheric oxygen concentrations. Reduction of nitrate under

48 aerobic and semi-aerobic conditions did not result in significant enhancements in carbon dioxide

49 production or total electron flow rate to electron acceptors. The genomes of these six isolates

50 were sequenced and targeted RT-qPCR revealed a wide diversity of regulatory controls on the

51 nitrate reductase(s). The results suggest that aerobic nitrate reduction can occur in diverse

52 bacteria, have multiple types of physiological controls, and can occur independently of the gas-

53 forming reactions of denitrification. Thus, it is an unappreciated fate of nitrate in soil. 
55 Keywords: Aerobic nitrate reduction; Bacterial genome; Dissimilatory nitrate reductase; Nitrite

56 production

57

58

59

60 


\section{Introduction}

Anthropogenic nitrogen $(\mathrm{N})$ production has led to new challenges in understanding how

63 excess $\mathrm{N}$ cycles in natural and managed ecosystems (Schlesinger, 2009; Fowler et al., 2013). A

64 particular problem is that excess nitrate can potentially be transferred from soil to small streams

65 and shallow groundwater, to rivers, and ultimately to coastal marine ecosystems where it fuels

66 eutrophication (Carpenter et al., 1998). This flow from soil to aquatic ecosystems can be

67 mitigated to some extent, since nitrate can be assimilated by plants and bacteria or reduced to

68 either ammonium (DNRA) or gaseous end products through microbial dissimilatory processes.

69 Microbial denitrification, the stepwise reduction of nitrate to dinitrogen via nitrite, nitric oxide,

70 and nitrous oxide, can potentially alleviate the negative effects of nitrate leaching from soils.

71 Denitrification is frequently viewed as a tightly coupled pathway whose activity is

72 inversely correlated with oxygen $\left(\mathrm{O}_{2}\right)$ levels, and thus has been studied mostly in soils with very

73 low $\mathrm{O}_{2}$ concentrations. The typical denitrifier is a facultative anaerobe that preferentially utilizes

$74 \mathrm{O}_{2}$ as an electron acceptor and restricts electron flow towards $\mathrm{N}$-oxides as long as $\mathrm{O}_{2}$ is available

75 (Shapleigh, 2012; Bergaust et al., 2011). However, studies on model denitrifiers have shown that

76 different steps in the pathway can be differentially controlled by $\mathrm{O}_{2}$, and the reason that $\mathrm{O}_{2}$

77 quenches the process may lie as much with chemical constraints as with physiological necessities

78 (Martinez-Espinosa et al., 2011; Shapleigh, 2011; Bateman and Baggs, 2005). For example, the

79 rapid chemical reaction of $\mathrm{NO}$ with $\mathrm{O}_{2}$ may be the reason why the production and reduction of

$80 \mathrm{NO}$ is the part of the pathway most tightly regulated in the presence of $\mathrm{O}_{2}$ (Bergaust et al., 2008;

81 Hartsock and Shapleigh, 2010; Watmough et al., 1999). In contrast, nitrate and nitrite do not

82 readily react with $\mathrm{O}_{2}$, and thus reduction of nitrate to nitrite is adjusted to best fit physiological 
83 necessities (Dalsgaard et al., 2014; Hartsock and Shapleigh, 2011; Sears et al., 2000; Martinez-

84 Espinosa et al., 2011).

85 Given that the multiple enzymes in the denitrification pathway do not necessarily have

86 tightly linked expression, it is reasonable to postulate that specific steps in the pathway function

87 independently. More specifically, there is no reason to assume that the first step in the pathway is

88 obligatorily linked to any of the remaining three steps, and thus, this step could occur under less

89 stringent $\mathrm{O}_{2}$ control resulting in an underappreciated source of nitrite. For example, Su et al.

90 (2011) and Isobe et al. (2012) showed circumstantially that nitrite production in acidic soils is

91 necessary to balance the budget of the chemically converted nitrous acid (HONO) compound

92 found in the atmosphere (Isobe et al., 2012; Su et al., 2011). Oswald et al. (2013) provided

93 evidence that neutral-to-basic soils in arid and arable areas show relatively high emission fluxes

94 of $\mathrm{HONO}$ and $\mathrm{NO}$ in nitrite rich soils, accounting for up to $50 \%$ of the reactive $\mathrm{N}$ release from

95 soil (Oswald et al., 2013). Chemodenitrification of nitrite has also resulted in the production of

96 gaseous $\mathrm{N}-o x i d e s$, with the reactive free radical $\mathrm{NO}$ as the major product (Thorn and Mikita,

97 2000; Davidson, 1992; Stuven et al., 1992). As chemodenitrification occurs when soil $\mathrm{pH}$ is $<5$

98 (Chalk and Smith, 1983), this process is likely significant in soils of the northeastern USA

99 (Kulkarni et al., 2013). Another possible abiotic fate of nitrite is the binding to soil via the so-

100 called nitrosation process (Smith and Tiedje, 1979; Matocha et al., 2012). This fate could explain

101 nitrate fixation onto soil organic matter that has been suggested as a sink for added

102 anthropogenic $\mathrm{N}$ in some forest ecosystems (Davidson et al., 2003).

103 The production of nitrite from nitrate in soils under oxic conditions has been shown by a

104 few other studies. Previous work by Carter et al. (1995) has described heterotrophic bacterial

105 isolates from soil capable of nitrate reduction in the presence of atmospheric oxygen, which has 
106 been referred to as aerobic nitrate reduction (ANR) and will be the term used here (Carter et al., 107 1995). Also, Vega-Jarquin et al. (2008) demonstrated ANR in soil from an alkaline lake bed in

108 Mexico when incubated in 100\% atmospheric $\mathrm{O}_{2}$ and in the presence of acetylene, a nitrification 109 inhibitor (Vega-Jarquin et al., 2008).

110 There is still limited understanding of the bacteria capable of performing ANR. Here, we

111 examine ANR in a range of soil types using an oxidized carbon source, succinate, with the

112 addition of nitrification and nitrate assimilation inhibitors in order to provide a more detailed

113 understanding of the eco-physiological context of ANR, including the determination of the $\mathrm{O}_{2}$

114 concentration at the onset of nitrate reduction in bacterial isolates demonstrating the ANR

115 phenotype. With these bacterial isolates we also investigated the diversity of regulation of the

116 dissimilatory nitrate reductase(s), which include the membrane-associated nitrate reductase (Nar)

117 and a periplasmic enzyme (Nap). The results of this work suggests that ANR is a common, yet

118 underappreciated trait, and this pathway may make a significant but still unclear contribution to

119 the soil nitrogen cycle.

\section{2. Methods}

122 2.1. Experimental sites and soils

123 Soils were collected in September 2010 from four sites near Ithaca, NY (Table 1). The

124 soil at the agricultural field site and second-growth forest site at McGowan Farm are classified as

125 an Alfisol (mesic Glossoboric Hapludalf; USDA Classification) derived from sandy outwash

126 with a fine loamy texture (Beatty and Stone, 1986; Castrillo et al., 2007). The agricultural field

127 site and second-growth forest site at Smith Woods are Alfisol (mesic Psammentic Hapludalf;

128 USDA classification) with a sandy texture (Beatty and Stone, 1986; Marks et al., 1999). Two 
129 forested wetland sites, Sapsucker Woods and Stewart Park, were also sampled. In both sites,

130 trees occur on elevated hummocks surrounded by water-filled pits, which are 0-40 cm deep. A

131 fragipan soil horizon about $1 \mathrm{~m}$ deep prevents drainage and maintains a high water table. The

132 soil at the Sapsucker Woods site is classified as an Inceptisol (mesic Mollic Endoaquept; USDA

133 Classification), which has a fine-loamy texture and is non acidic (Miller et al., 2004). Soil at the

134 Stewart Park site is also classified as an Inceptisol (mesic Fluvaquentic Endoaquept; USDA

135 Classification). At both of the forested wetland sites soils were collected separately from the

136 hummocks and pits. In July 2011 samples were taken from a forested site at the Hubbard Brook

137 Experimental Forest (HBEF) within the White Mountain National Forest, West Thornton, NH.

138 Soils at this second-growth forest site are classified as Spodosol (Typic Haplorthod; USDA

139 Classification) derived from granitic glacial till with sandy-loam to loamy-sand texture (Adams 140 et al., 2008).

141 At each of the sites described above, soil samples (roughly $200 \mathrm{~g}$ each) were collected

142 from three randomized locations from the $0-10 \mathrm{~cm}$ depth interval. Samples were stored for $<60$

143 minutes in plastic bags before being assayed. Soil $\mathrm{pH}$ was measured with a glass electrode in a

144 1:5 soil-water slurry. Soil moisture content was calculated as ((wet weight-dry weight)/wet

145 weight) $\times 100$.

$146 \quad<$ Insert Table 1 here $>$

$148 \quad$ 2.2. Assay for ANR

149 Analysis of ANR activity began within 60 minutes of soil collection. Soil ( $0.5 \mathrm{~g}$ fresh-

150 weight) was added to a $1 \mathrm{ml}$ solution in a $1.5 \mathrm{ml}$ microcentrifuge tube. The solutions added to the 151 soils were: 1) deionized water (W), 2) deionized water with $0.03 \mathrm{mg} \mathrm{N}-\mathrm{KNO}_{3} \mathrm{~g}^{-1}$ fresh-weight 
152 soil (W+N), 3) Sistrom's medium (Lueking et al., 1978; SIS); 4) SIS plus 0.03 mg N-KNO 3 g $^{-1}$

153 fresh-weight soil (SIS+N); 5) SIS+N and $300 \mathrm{mM}$ dicyandiamide (DCD) (SIS+N+DCD), and 6)

$154 \mathrm{SIS}+\mathrm{N}$ and $113 \mathrm{mM}$ ammonium sulfate (SIS $+\mathrm{N}+\mathrm{NH}_{4}$ ). Succinate, a relatively oxidized carbon

155 source found in soils, was the carbon source in the Sistrom's medium and was used to provide

156 the approximate redox level to cell biomass (McKinlay and Harwood, 2011), where Carter et al.

157 (1995) previously used a reduced carbon source of butyrate to demonstrate ANR. DCD was used

158 as a nitrification inhibitor (Giltrap et al., 2010; Davies and Williams, 1995) and excess

159 ammonium sulfate was used to ensure nitrite production was not a consequence of the

160 assimilatory nitrate reductase (Giltrap et al., 2010; Vega-Jarquin et al., 2008).

161 All incubations were done in triplicate and agitated continuously by vortex under

162 atmospheric conditions for up to five hours. Nitrite accumulation was measured after 30 minutes,

16360 minutes, three hours, and five hours of incubation. Nitrite was determined by adding $50 \mu 1$ of

164 the soil slurry to $900 \mu \mathrm{l}$ phosphate buffer and $1 \mathrm{~mL}$ of Griess reagents $\mathrm{A}$ and B (Roussel-Delif et

165 al., 2005). Intensity of colorimetric change was measured on the spectrophotometer at an

166 absorbance of $540 \mathrm{~nm}$.

167

168 2.3. Classification and identification of isolates

169 Bacterial isolates were isolated under well-aerated, heterotrophic conditions from the

170 soils collected from the various sites. Bacteria capable of ANR were isolated as described in

171 Roco et al. (in press). In brief, isolates from soil were incubated aerobically for 24 hours at $30^{\circ} \mathrm{C}$

172 in a 96-well plate on Sistrom's agar medium supplemented with $113 \mathrm{mM}\left(\mathrm{NH}_{4}\right)_{2} \mathrm{SO}_{4}$ and $10 \mathrm{mM}$

$173 \mathrm{KNO}_{3}$ before being tested for nitrite production (using $20 \mu 1$ of the Griess reagents).

174 Approximately 50 isolates capable of nitrite production under these conditions were selected for 
175 16S rDNA gene sequence using the $8 \mathrm{~F}$ and 1492R universal primers and a previously described

176 PCR protocol (Roco et al. in press). Amplicons were sent for Sanger sequencing at the Cornell

177 University Core Laboratory Center.

178 Isolates capable of ANR were also tested for growth in an anaerobic jar on Sistrom's

179 medium with $10 \mathrm{mM} \mathrm{KNO}_{3}$. Anoxic conditions were maintained using the GasPak ${ }^{\mathrm{TM}}$ system as

180 described by the manufacturer (Becton, Dickinson and Company). Six isolates capable of ANR

181 were chosen for full genome sequencing based on phenotypic traits. Details of their sequencing

182 and annotation can be found elsewhere (Roco et al., 2016).

183

184 2.4. Gas and nitrite measurements

185 The six bacterial isolates were raised from frozen stocks and pre-cultured at $30^{\circ} \mathrm{C}$ under 186 aerobic conditions in Sistroms' medium with no amended nitrate. These cultures were used as

187 inocula for two sets of incubation experiments, which were performed in triplicate at $30^{\circ} \mathrm{C}$ in 120

$188 \mathrm{~mL}$ glass vials with $50 \mathrm{~mL}$ liquid Sistrom's medium. The experiments were set up to assess: 1)

189 apparent critical $\left[\mathrm{O}_{2}\right]$ threshold for ANR; and 2) the impact of ANR on apparent growth rates and

190 election (e-)-flow (isolates 2, 5 and 16 only). Since both $\mathrm{O}_{2}$ and $\mathrm{N}$-oxides produced were

191 monitored, it was possible to estimate the $\mathrm{e}^{-}$-flow rate $\left(\mathrm{V}_{\mathrm{e}-\text { - }}\right.$ to $\mathrm{O}_{2}$ and $\mathrm{N}$-oxides, $\mu$ mol vial $\left.{ }^{-1} \mathrm{~h}^{-1}\right)$

192 for each time increment between two samplings. For the first experiments examining the $\mathrm{O}_{2}$

193 threshold of ANR, aerobic pre-cultures of each of the six isolates were transferred to vials to

194 initial $\mathrm{OD}_{600} \leq 0.035$, starting at ambient $\left[\mathrm{O}_{2}\right]$ and containing either 1 or $2 \mathrm{mM} \mathrm{KNO}$. The set-up

195 for the second experiment exploring the impact of ANR on growth rate was similar to the first

196 experiment, except that nitrate was added approximately 2.5 hours into the incubations to assess

197 whether this had any apparent effect on growth and electron flow rates. After inoculation into 
198 sealed vials, cultures were stirred continuously at 500-700 rpm to ensure complete dispersal of

199 cells and proper gas exchange between liquid and headspace. We used a robotic incubation

200 system (Molstad et al., 2007) to monitor headspace gases $\mathrm{O}_{2}$ and $\mathrm{CO}_{2}$ every $\sim 0.5-1.5$ hours). The

201 combination of headspace and liquid measurements produced detailed datasets so the

202 concentrations of $\mathrm{O}_{2}, \mathrm{CO}_{2}$ and $\mathrm{N}$-oxides could be accurately calculated for each sampling. This

203 facilitated assessment of respiration rates and $\mathrm{e}^{-}$-flow to each terminal electron acceptor (as

204 described in Bergaust et al., 2010; Hassan et al., 2014).

205 Nitrite measurements were carried out separately throughout the incubations by injecting

$20610 \mu \mathrm{L}$ of withdrawn liquid culture into a purged vessel containing $1 \% \mathrm{w} / \mathrm{v}$ sodium iodide (NaI)

207 in acetic acid, reducing the injected nitrite to NO (MacArthur et al., 2007). $\mathrm{N}_{2}$ was bubbled

208 continuously through the purge vessel to maintain anaerobic conditions and was also the carrier

209 gas transporting NO to the connected chemiluminescence detector (Nitric Oxide Analyzer NOA

210 280i, General Electric).

211

212 2.5. RNA extraction and RT-qPCR

213 Genome sequencing of the six isolates allowed for specific primer design for each of the

214 nitrate reductase genes within each isolate. Further details of growth conditions, harvesting times

215 and real time quantitative PCR protocols can be found elsewhere (Roco et al. in press). In brief,

216 isolates were grown in flasks in triplicate with either a foam or rubber stopper, for aerobic or

217 hypoxic conditions, respectively, in Sistrom's medium with or without $10 \mathrm{mM} \mathrm{KNO}_{3}$ and cells

218 were harvested during various growth stages based on detectable nitrite levels. The expression of

219 nar and nap was estimated relative to their respective standard curves (log-linear regression of

220 threshold cycle $\left(C_{T}\right)$ value against log copy number). A list of the specific primers used, their 
221 annealing temperature, and qPCR efficiencies of the standard curves can be found in Table S1.

222 Real-time qPCRs were set up in triplicate and the results are given as mRNA copies $\mu^{-1}$ total 223 RNA.

\section{3. Results}

\section{3.1. ANR activity in soil}

227 An initial assay was undertaken as a means to identify soils in which ANR occurred. Soil 228 with additions of water, water plus nitrate, or Sistrom's medium produced only trace amounts of 229 nitrite (Fig. 1). In contrast, additions of nitrate plus Sistrom's medium led to nitrite production in 230 nearly all the soils examined, with nitrite being detected as early as 30 minutes after incubations 231 began (data not shown). The average accumulation of nitrite after 5 hours of incubation in 232 samples with nitrate plus Sistrom's medium was 2 to $14 \mu \mathrm{g} \mathrm{N}-\mathrm{NO}_{2} \mathrm{~g}^{-1}$ fresh-weight soil (Fig. 1), 233 which was $7.5-50 \%$ of the $28 \mu \mathrm{g} \mathrm{N}-\mathrm{NO}_{3}$ added per gram of fresh soil. Additions of either DCD 234 or excess ammonium along with nitrate plus Sistrom's medium did not significantly change the 235 amount of nitrite accumulation ( $\mathrm{p} \leq 0.05$, two-way ANOVA) beyond that exhibited by soil with 236 added nitrate and Sistrom's medium alone.

237 The greatest rates of ANR occurred in the forested wetland sites when both carbon and 238 nitrate was present (Fig. 1). Notably, in the wetland sites, the amount of nitrite accumulation 239 differed significantly between the pits and hummocks ( $\mathrm{p} \leq 0.05$, two-way ANOVA)(Fig. S1).

240 The Stewart Park hummock soil was the only site that had significant nitrite accumulation in the 241 absence of added nitrate when incubated with a carbon source (Fig. 1, Fig. S1). The hummock at 242 Sapsucker Woods only showed nitrite accumulation when incubated with carbon, nitrate and 243 added ammonium (Fig. S1). Nitrite production from the pits required both carbon and nitrate, 
244 and the Stewart Park pit showed the most noteworthy increase (Fig. 1). At both sites hummocks

245 were significantly drier than the pits, with a soil moisture content $30-50 \%$ lower, and $\mathrm{pH}$ 0.6-0.8

246 units lower (Table 1).

$247 \quad<$ Insert Figure 1 here $>$

\subsection{Isolates with ANR phenotype}

A total of 250 bacterial strains were isolated under aerated, heterotrophic conditions from

251 the various soils. Approximately 90 of the 250 isolates exhibited ANR and were grouped based

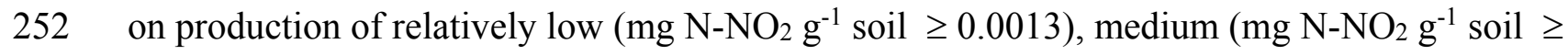

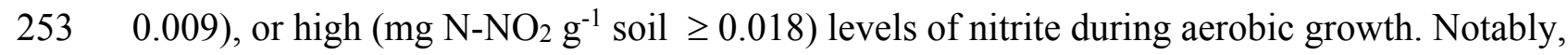

254 most of the isolates had less nitrite production in well-mixed liquid than on solid agar. In general,

255 soils with low ANR activity yielded isolates with a low level of nitrite production, as bacterial

256 isolates from the three forested sites yielded the highest proportion of low nitrite producing

257 isolates compared to the other sites (Fig. S2). In contrast, soils with the greatest ANR activity

258 produced about equal numbers of low and high nitrite producing isolates (Fig. S2). Among the

25990 isolates, only about $30 \%$ were able to grow with nitrate as the sole electron acceptor (data not

260 shown). Phylogenetic characterization of the isolates revealed that Actinobacteria, Firmicutes,

261 and alpha, beta and gamma Proteobacteria. Gammaproteobacteria constituted $42 \%$ of the total

262 isolates, with pseudomonads as the majority, constituting $31 \%$ of the gammaproteobacteria.

263 To gain more insight into the diversity of ANR phenotypes, six strains were examined for

264 detailed timing of nitrite production in relation to $\mathrm{O}_{2}$ concentration (Fig. 2). Two isolates $(5,16)$

265 had rapid net nitrite production rates (initial $v_{\mathrm{NO} 2-}$ ) when $\mathrm{O}_{2}$ was 57 to $86 \%$ of the ambient level.

266 Two isolates $(2,28)$ had lower initial $v_{\mathrm{NO} 2-}$ when $\mathrm{O}_{2}$ was 35 to $66 \%$ of ambient. Finally, two 
267 isolates $(21,26)$ had low initial $v_{\mathrm{NO}}$ - when $\mathrm{O}_{2}$ was 60 to $84 \%$ of ambient. Isolates $2,5,16$, and

26828 did not reduce nitrite further, and thus nearly all of the added nitrate-N was recovered as

269 nitrite. Isolates 21 and 26 accumulated nitrite only transiently, consistent with their abilities to

270 grow as denitrifiers.

271 Further measurements in isolates 2, 5 and 16 indicated there was no change in $\mathrm{CO}_{2}$

272 production or total electron flow ( $\mathrm{V}_{\mathrm{e}-\text { to }} \mathrm{O}_{2}$ or $\mathrm{N}$-oxides, $\mu \mathrm{mol}$ vial $\left.{ }^{-1} \mathrm{~h}^{-1}\right)$ with the addition of

273 nitrate to the medium during aerobic growth (data not shown). The complete denitrifiers, 21 and

27426 , were not assessed as they can reduce the nitrite which would confound the results, and isolate

27528 was a very slow grower and omitted for practical purposes.

$276 \quad<$ Insert Figure 2 here $>$

277

278 3.3. Nap and Nar genes

279 We sequenced the genomes of six isolates capable of ANR to examine the gene content

280 for nitrate reductase. The genomes were compared to previously published genomes in the

281 Department of Energy (DOE) Integrated Microbial Genomes (IMG) public database. Genome

282 analysis revealed that isolates 21 and 26 had the genes necessary for complete denitrification

283 (Fig. S3). Isolate 21 is related to Pseudomonas nitroreducens and has two clusters of genes

284 encoding membrane bound Nar. The two respiratory nitrate reductase alpha chain subunits

285 (NarG) share 71\% identity, indicating they are not paralogous. NarG in cluster 1 (locus tag

286 UB43_11370) has significant sequence similarity with proteins from Pseudomonas aeruginosa

287 (90\% identity). NarG from cluster 2 (locus tag UB43_19730) is only 70\% identical to NarG from

288 Pseudomonas aeruginosa but about 80\% identical with Nar from various Halomonas species,

289 another $\gamma$-proteobacterium but a member of the family Halomonadaceae. Isolate 26, classified as 
290 a member of the genus Ralstonia, contains a single nitrate reductase cluster that encodes a Nap-

291 type protein. This protein has high identity to orthologs in other Ralstonia. However, many

292 Ralstonia usually have one or two copies of the genes encoding the Nar type enzyme. At this

293 time, there is only one other Ralstonia strain like isolate 26 in having Nap but no Nar in the DOE

294 IMG public database, making this particular arrangement rare among members of this genus.

295 Isolates 2 and 5 are both pseudomonads and have nitrate reductase as their only

296 dissimilatory N-oxide reductase. Interestingly, both strains have gene clusters for both Nar and

297 Nap type nitrate reductases. Examination of the genomes of 728 other pseudomonads in the DOE

298 IMG database (as of 05/14/2015) found only one other strain with both Nar and Nap that lacked

299 all other downstream denitrification N-oxide reductases, making this arrangement rare in this

300 dataset. Nearly all the sequenced pseudomonad strains contained Nar and $<30 \%$ contained both

301 Nar and Nap. The orthologous clusters in isolates 2 and 5 are identical in gene content and

302 organization. These strains are not siblings, however, as 492 genes in isolate 5, out of a predicted

303 total of $\sim 5000$ genes, do not have obvious orthologs, defined as $>30 \%$ identity, to isolate 2 .

304 Likewise, 643 genes in isolate 2, out of a total of $\sim 5300$ genes, are not found in isolate 5 .

305 However, conserved regions are highly similar, with DNA identity of about $88 \%$.

306 Isolate 16, a member of the Burkholderiaceae family, contains a Nar encoding gene

307 cluster. This cluster is identical in organization with most orthologs from other Ralstonia strains.

308 The regions of the genome flanking the Nar encoding gene clusters are not conserved among the

309 strains, however. For example, the eight genes downstream of this cluster are present in other

310 Ralstonia strains but not with the same organization as in isolate 16 . Isolate 28 , a member of the

311 order Actinomycetales, is the only gram positive among the characterized isolates and has a Nar 
312 type nitrate reductase. Nar are fairly common among the order Actinomycetales and the

313 predicted Nar proteins from 28 are most closely related to proteins from members of this order.

315 3.4. Expression of nitrate reductase(s) in the isolates

316 In order to determine whether the dissimilatory nitrate reductase genes displayed similar

317 or contrasting patterns of expression among the six isolates, qPCR was performed on RNA

318 isolated from cells growing under various conditions. Results from the nitrate reductase RT-

319 qPCR are summarized in Table 2. The two complete denitrifiers, isolates 21 and 26, were found

320 to have dissimilar patterns of nitrate reductase expression. Only one of the two nar clusters in

321 isolate 21 , cluster 1 , showed changes in copy number, with an increase in expression during

322 oxygen limitation in combination with $\left.\mathrm{NO}_{3}{ }^{-}\left(\mathrm{AE} \_ \text {HighOD_NO}\right)_{3}\right)$, and the highest expression in

323 the anoxic treatment with nitrate (AN_HighOD_NO S $_{3}$. The other nar cluster showed virtually no

324 transcription under any conditions. The nap in isolate 26 showed significant transcription under

325 all conditions. Cells from low-density oxic conditions showed the lowest expressions, but this

326 increased in higher density cultures, regardless of the presence of nitrate (AE_HighOD).

327 Expression in the high-density cultures was equivalent to that seen in cells isolated under

328 denitrifying conditions.

329 Isolates 2 and 5 had dissimilar expression patterns despite their high sequence

330 similarities. nar in isolate 5 was controlled by the presence of nitrate, regardless of $\mathrm{O}_{2}$, showing

331 high transcription in both $\mathrm{AE} \_$LowOD_NO 3 and $\mathrm{AE} \_$HighOD_NO 3 . Comparatively, nap had

332 low background expression levels in isolate 5 under all conditions and increased as $\left[\mathrm{O}_{2}\right]$

333 decreased in nitrate supplemented medium ( $\left.\mathrm{AE}_{-} H i g h \mathrm{H} \mathrm{NO}_{3}\right)$. The expression of nap in isolate

3342 also occurred at high cell density but did not require added nitrate (AE_HighOD). nar in this 
335 isolate had a comparatively low level of transcription under all conditions, only showing a

336 limited increase in expression during oxygen limitation in $\mathrm{NO}_{3}{ }^{-}$amended medium

337 (AE_HighOD_NO3).

338 Strain 16 showed a clear increase in nar expression in response to oxygen limitation, 339 especially in the presence of $\mathrm{NO}_{3}^{-}\left(\mathrm{AE} \_\mathrm{HighOD} \_\mathrm{NO}_{3}\right)$. Transcription of nar was relatively low

340 for isolate 28 under all conditions. However, this gene cluster showed a modest increase in copy

341 number in late exponential phase with the presence of nitrate (AE_HighOD_NO 3 ).

$342 \quad<$ Insert Table 2 here $>$

\section{4. Discussion}

345 We examined ANR in a range of soils in the northeastern USA, and our results suggest

346 that ANR is an underappreciated sink for nitrate in soil. Despite being mostly ignored in soil

347 science and soil ecological work, a few studies have quantified ANR in soils (Russow et al., 348 2009; Isobe et al., 2012; Müller et al., 2006) and report nitrite production rates of $<1 \mu \mathrm{g} \mathrm{g}^{-1} \mathrm{hr}^{-1}$.

349 Here, we found rates from 0.5 to $2.8 \mu \mathrm{g} \mathrm{N}^{-N_{2}} \mathrm{~g}^{-1} \mathrm{hr}^{-1}$, which resulted in the reduction of 7.5-

$35050 \%$ of the added nitrate. Our study advances the understanding of ANR in natural ecosystems

351 for at least two reasons. The first is that we measured ANR within a few hours of soil collection,

352 suggesting that enzymes capable of the process are pre-existing in soils. Secondly, we

353 characterized several bacteria able to perform ANR and found a diversity of physiological

354 controls on the process. This implies that ANR is more diverse than previously suspected.

355 The highest rate of nitrite production in all of the soils occurred with additions of nitrate

356 plus carbon, i.e. Sistrom's medium (Fig. 1), suggesting that ANR is a heterotrophic process

357 associated with respiration. Also, because all of the soils exhibited nitrite production with the 
358 addition of a nitrification inhibitor, we are confident that the process was not simply a

359 consequence of nitrification, but rather due to a different group of bacteria. The highest rate of

360 nitrite production occurred in the soils from the forested wetland sites, but the contrast of nitrite

361 production between the pits and hummocks suggest different contributing processes.

362 Nitrification may be a major contributor of nitrite production in the hummocks at these forested

363 wetland sites. This might explain the finding at Sapsucker Woods, where the hummocks

364 experienced nitrite production only when excess ammonium was available (Fig. S1). The fact

365 that nitrite was produced in the hummocks at Stewart Park with carbon alone also suggests an

366 addition of nitrate via nitrification (Fig. 1, Fig. S1). In contrast, the pit soils from both Stewart

367 Park and Sapsucker Woods suggests nearly all the nitrite production occurred via ANR, as no

368 nitrite was detected without the addition of both carbon and nitrate (Fig. 1). Soils in forested

369 wetlands generally have high levels of available organic carbon (Rosenblatt et al., 2001), which

370 is consistent with the notion that heterotrophic metabolism helps to sustain ANR.

371 Isolation of bacteria capable of ANR from these soils proved surprisingly easy. However,

372 the percentage of isolates with this phenotype is likely inflated due to the isolation procedure,

373 and is not likely representative of the entire soil community. Taxonomic identification of the

374 ANR strains revealed a diversity of genera. This is similar to what is seen with denitrification

375 (Bakken et al., 2012) and indicates these processes are not restricted to particular taxonomic

376 groups but can be adapted to fit the physiological needs of many organisms. While ANR has

377 been reported previously (Carter et al., 1995; Vega-Jarquin et al. 2008), this is the first study to

378 accurately measure the $\left[\mathrm{O}_{2}\right]$ levels at the onset of nitrite production. This is an important

379 parameter to measure to ensure nitrite production can occur at high $\mathrm{O}_{2}$ saturation, particularly

380 since we were not able to measure $\mathrm{O}_{2}$ saturation during soil incubations or initial isolate 
381 characterization. The fact that the onset of nitrite production occurred between $45-86 \%$

382 atmospheric $\mathrm{O}_{2}$ (Fig. 2) in the six isolates indicates the isolate screen was effective at identifying

383 bacteria capable of reducing nitrate at nearly saturated $\mathrm{O}_{2}$. It is noteworthy that this $\left[\mathrm{O}_{2}\right]$ is much

384 higher than the onset of nitrite reduction in some model denitrifiers, which has been reported at

$385 \leq 1.5 \%$ atmospheric $\left[\mathrm{O}_{2}\right]$, showing that particular steps in the denitrification pathway have very

386 different $\mathrm{O}_{2}$ thresholds (Bakken et al., 2012; Bergaust et al., 2011; Bergaust et al., 2008).

387 Although the ANR phenotype was common in our soils and the isolates were

388 representative of common soil genotypes, the nitrate reductase genotypes of isolates 2, 5 and 26

389 were relatively unique compared to full genomes available at the DOE IMG database $(19,000$

390 strains as of June 2014). This demonstrates there is a wide diversity of nitrate reductase

391 arrangements in bacteria and particular assemblages are not restricted to particular taxonomic

392 groups or physiological processes. It should be noted, though, that the occurrence of nitrate

393 reductase is not rare, since $51 \%$ of the isolates in the DOE IMG database as of $06 / 2014$

394 possessed the genes encoding a dissimilatory nitrate reductase. Moreover, surveys of

395 denitrification genes in the environment reveal that nar and nap are more prevalent than the

396 genes involved in the production and consumption of $\mathrm{NO}$ and $\mathrm{N}_{2} \mathrm{O}$, suggesting that soils have a

397 high potential for nitrate reduction (Henry et al., 2006; Bru et al., 2011).

398 This common occurrence of the ANR phenotype in the environment brings into question

399 its physiological role to bacteria. This is of particular interest in the four sequenced isolates that

400 lacked a dissimilatory nitrite reductase, thereby limiting any physiological benefit of N-oxide

401 reduction to the reduction of nitrate to nitrite. Nitrate reduction to nitrite has a $\Delta \mathrm{G}_{0}^{\prime}$ of -161

$402 \mathrm{~kJ} / \mathrm{mol}$, making it possible to use this reaction to generate ATP. This is sufficient to support

403 growth under hypoxic conditions, but this does not explain why the strains characterized here 
404 express nitrate reductases under high [O $\left.\mathrm{O}_{2}\right]$ (Nishimura et al., 2007). In a previous study

405 investigating ANR, it was suggested that this trait might be used to dissipate excess electrons

406 (Carter et al., 1995). However, a more oxidized carbon source was used in this study, so it is

407 unlikely the disposal of excess electrons is the reason why ANR is utilized by the isolates

408 described here. None of the four isolates lacking nitrite reductase in this study showed evidence

409 of growth under anoxic conditions nor were respiration rates under oxic conditions with and

410 without added nitrate, measured by $\mathrm{CO}_{2}$ production and electron flow, significantly different in

411 isolates 2, 5 and 16. These results imply no physiological benefit in the co-respiration of $\mathrm{O}_{2}$ and

412 nitrate, a result seemingly at odds with the ready isolation of bacteria with this phenotype from

413 soil. Defining the physiological role of these proteins likely await more detailed physiological

414 investigations under diverse growth conditions.

415 In addition to the diversity of nitrate reductase types found in these isolates, a range of

416 regulatory patterns was also observed. For example, despite the fact that the two isolates with

417 both Nar and Nap, isolates 2 and 5, had very similar genotypes they demonstrated very different

418 nar and nap expression patterns. Isolate 5 had consistently much higher levels of nar and nap

419 expression than isolate 2, which correlated with higher rates of nitrite production. This diversity

420 in expression provides another demonstration that these nitrate reductases are being regulated to

421 best support the metabolic needs of the cell even if the rationale for these regulatory patterns are 422 not obvious.

423 We have developed an isolation protocol for bacteria capable of ANR, demonstrating the

424 common occurrence of this phenotype in soil, and have seen that ANR is not ammonium

425 dependent, but is carbon and nitrate dependent and oxygen independent. We have also

426 demonstrated that the bacterial isolates capable of ANR show an intricate phenotypic landscape, 
427 indicating new types of complexity within the denitrifying community. Our working hypothesis

428 is that ANR is a common, yet underappreciated trait, and that this pathway has the potential to

429 make a significant contribution to the soil nitrogen cycle. In terms of future understanding of

430 denitrification, it will be important to recognize that this first step cannot be assumed to be under

431 tight $\mathrm{O}_{2}$ control, as there is a wide disparity of $\mathrm{O}_{2}$ concentrations at the onset of nitrate reduction,

432 which, importantly, is higher than the onset of nitrite reduction. Without an adequate assessment

433 of aerobic nitrate reduction our understanding of factors controlling nitrate flux in soils remains

434 incomplete.

435

436 Acknowledgements

437 We thank Trever Smith and Yao Wong for their contributions to strain isolation. This

438 work was supported by the U.S. National Science Foundation (NSF) grant DEB \#1311335 and

439 by the Norwegian Research Council (FRIMEDBIO: 231282). Partial funding support was

440 provided by Cornell University Programs in Biogeochemisty and Environmental Biocomplexity

441 and Cross-Scale Biogeochemistry and Climate, both of which were and are supported by NSF

442 and the Atkinson Center for a Sustainable Future. The authors report no conflict of interest.

\section{Appendix. Supplementary data}

445 Supplementary data related to this article can be found in the online version, at $<$ insert

446 URL here>.

447

448 References 
Adams, M.B., Loughry, L., Plaugher comps., L., 2008. Experimental Forests and Ranges of the USDA Forest Service. General Technical Report NE-321 Revised, 178.

Bakken, L.R., Bergaust, L., Liu, B., Frostegard, A., 2012. Regulation of denitrification at the cellular level: a clue to the understanding of $\mathrm{N}_{2} \mathrm{O}$ emissions from soils. Philosophical Transactions of the Royal Society of London 367, 1226-1234.

Bateman, E.J., Baggs, E.M., 2005. Contributions of nitrification and denitrification to $\mathrm{N}_{2} \mathrm{O}$ emissions from soils at different water-filled pore space. Biology and Fertility of Soils 41, 379-388. doi:10.1007/s00374-005-0858-3

Beatty, S.W., Stone, E.L., 1986. The variety of soil microsites created by tree falls. Canadian Journal of Forest Research 16, 539-548. doi:10.1139/x86-094

Bergaust, L., Bakken, L.R., Frostegard, A., 2011. Denitrification regulatory phenotype, a new term for the characterization of denitrifying bacteria. Biochemical Society Transactions $39,207-212$.

Bergaust, L., Mao, Y., Bakken, L.R., Frostegard, A., 2010. Denitrification response patterns during the transition to anoxic respiration and posttranscriptional effects of suboptimal $\mathrm{pH}$ on nitrous oxide reductase in Paracoccus denitrificans. Applied and Environmental Microbiology 76, 6387-6396.

Bergaust, L., Shapleigh, J., Frostegard, A., Bakken, L., 2008. Transcription and activities of NOx reductases in Agrobacterium tumefaciens: the influence of nitrate, nitrite and oxygen availability. Environmental Microbiology 10, 3070-3081.

Bru, D., Ramette, A., Saby, N.P., Dequiedt, S., Ranjard, L., Jolivet, C., Arrouays, D., Philippot, L., 2011. Determinants of the distribution of nitrogen-cycling microbial communities at the landscape scale. The ISME Journal 5, 532-542. 
472 Carpenter, S.R., Caraco, N.F., Correll, D.L., Howarth, R.W., Sharpley, A.N., Smith, V.H., 1998.

473 Nonpoint pollution of surface waters with phosphorus and nitrogen. Ecological

$474 \quad$ Applications 8, 559-568.

475 Carter, J.P., Hsiao, Y.H., Spiro, S., Richardson, D.J., 1995. Soil and sediment bacteria capable of 476 aerobic nitrate respiration. Applied and Environmental Microbiology 61, 2852-2858.

477 Castrillo, L.A., Thomsen, L., Juneja, P., Hajek, A.E., 2007. Detection and quantification of 478 Entomophaga maimaiga resting spores in forest soil using real-time PCR. Mycological 479 Research 111, 324-331. doi: 10.1016/j.mycres.2007.01.010

480 Chalk, P.M., Smith, C.J., 1983. Chemodenitrification, in: Freney, J.F., Simpson, J.R. (Eds.), Gaseous loss of nitrogen from plant-soil systems. Martinus Nijhoff, The Hague, pp. 65-

Dalsgaard, T., Stewart, F.J., Thamdrup, B., De Brabandere, L., Revsbech, N.P., Ulloa, O., Canfield, D.E., DeLong, E.F., 2014. Oxygen at nanomolar levels reversibly suppresses process rates and gene expression in anammox and denitrification in the oxygen minimum zone off northern Chile. mBio 5. doi:10.1128/mBio.01966-14

Davidson, E.A., 1992. Sources of nitric-oxide and nitrous-oxide following wetting of dry soil. Soil Science Society of America Journal 56, 95-102. nitrate in forest ecosystems: the ferrous wheel hypothesis. Global Change Biology 9,

492 Davies, D.M., Williams, P.J., 1995. The effect of the nitrification inhibitor dicyandiamide on 493 nitrate leaching and ammonia volatilization - a UK nitrate sensitive areas perspective.

494 Journal of Environmental Management 45, 263-272. 
Fowler, D., Coyle, M., Skiba, U., Sutton, M.A., Cape, J.N., Reis, S., Sheppard, L.J., Jenkins, A., Grizzetti, B., Galloway, J.N., Vitousek, P., Leach, A., Bouwman, A.F., Butterbach-Bahl, K., Dentener, F., Stevenson, D., Amann, M., Voss, M., 2013. The global nitrogen cycle in the twenty-first century. Philosophical Transactions of the Royal Society of London. Series B, Biological Sciences 368 (1621), 20130164. doi:10.1098/rstb.2013.0164

Giltrap, D.L., Singh, J., Saggar, S., Zaman, M., 2010. A preliminary study to model the effects of a nitrification inhibitor on nitrous oxide emissions from urine-amended pasture. Agriculture, Ecosystems \& Environment 136, 310-317.

Hartsock, A., Shapleigh, J.P., 2011. Physiological roles for two periplasmic nitrate reductases in Rhodobacter sphaeroides 2.4.3 (ATCC 17025). Journal of Bacteriology 193, 6483-6489.

Hartsock, A., Shapleigh, J.P., 2010. Mechanisms of oxygen inhibition of nirK expression in Rhodobacter sphaeroides. Microbiology 156 (Pt 10), 3158-3165.

Hassan, J., Bergaust, L.L., Wheat, I.D., Bakken, L.R., 2014. Low probability of initiating nirS transcription explains observed gas kinetics and growth of bacteria switching from aerobic respiration to denitrification. PLoS Computational Biology 10, e1003933. doi: 10.1371/journal.pcbi.1003933

Henry, S., Bru, D., Stres, B., Hallet, S., Philippot, L., 2006. Quantitative detection of the nosZ gene, encoding nitrous oxide reductase, and comparison of the abundances of 16S rRNA, narG, nirK, and nosZ genes in soils. Applied and Environmental Microbiology 72, 51815189.

Isobe, K., Koba, K., Suwa, Y., Ikutani, J., Kuroiwa, M., Fang, Y., Yoh, M., Mo, J., Otsuka, S., Senoo, K., 2012. Nitrite transformations in an N-saturated forest soil. Soil Biology \& Biochemistry 52, 61-63. 
518 Kulkarni, M. V, Burgin, A.J., Groffman, P.M., Yavitt, J.B., 2013. Direct flux and ${ }^{15} \mathrm{~N}$ tracer

519 methods for measuring denitrification in forest soils. Biogeochemistry 117, 359-373. doi: $10.1007 / \mathrm{s} 10533-013-9876-7$

521 Lueking, D.R., Fraley, R.T., Kaplan, S., 1978. Intra Cytoplasmic membrane synthesis in synchronous cell populations of Rhodopseudomonas sphaeroides fate of old and new membrane. Journal of Biological Chemistry 253, 451-457.

524 MacArthur, P.H., Shiva, S., Gladwin, M.T., 2007. Measurement of circulating nitrite and Snitrosothiols by reductive chemiluminescence. Journal of Chromatography B 851, $93-$

Marks, P.L., Gardescu, S., Hitzhusen, G.E., 1999. Windstorm damage and age structure in an old 105. doi:10.1016/j.jchromb.2006.12.012 growth forest in central New York. Northeastern Naturalist 6, 165-176.

Martinez-Espinosa, R.M., Cole, J.A., Richardson, D.J., Watmough, N.J., 2011. Enzymology and ecology of the nitrogen cycle. Biochemical Society Transactions 39, 175-178.

531 Matocha, C.J., Dhakal, P., Pyzola, S.M., 2012. Chapter Four - The role of abiotic and coupled biotic/abiotic mineral controlled redox processes in nitrate reduction. Advances in

534 McKinlay, J.B., Harwood, C.S., 2011. Calvin cycle flux, pathway constraints, and substrate oxidation state together determine the $\mathrm{H}_{2}$ biofuel yield in photoheterotrophic bacteria.

537 Miller, D.N., Yavitt, J.B., Madsen, E.L., Ghiorse, W.C., 2004. Methanotrophic activity, 538 abundance, and diversity in forested swamp pools: Spatiotemporal dynamics and influences on methane fluxes. Geomicrobiology Journal 21, 257-271. doi: $10.1080 / 01490450490438766$ 
541 Molstad, L., Dorsch, P., Bakken, L.R., 2007. Robotized incubation system for monitoring gases

$542\left(\mathrm{O}_{2}, \mathrm{NO}, \mathrm{N}_{2} \mathrm{O}, \mathrm{N}_{2}\right)$ in denitrifying cultures. Journal of Microbiological Methods $71,202-$ 543211.

544 Nishimura, T., Vertes, A.A., Shinoda, Y., Inui, M., Yukawa, H., 2007. Anaerobic growth of 545 Corynebacterium glutamicum using nitrate as a terminal electron acceptor. Applied

546 Microbiology and Biotechnology 75, 889-897. doi: 10.1007/s00253-007-0879-y

547 Oswald, R., Behrendt, T., Ermel, M., Wu, D., Su, H., Cheng, Y., Breuninger, C., Moravek, A., 548 Mougin, E., Delon, C., Loubet, B., Pommerening-Roser, A., Sorgel, M., Poschl, U., 549 Hoffmann, T., Andreae, M.O., Meixner, F.X., Trebs, I., 2013. HONO emissions from soil 550 bacteria as a major source of atmospheric reactive nitrogen. Science 341, 1233-1235. 551 doi: $10.1126 /$ science. 1242266

552 Roco, C.A., Bergaust, L.L., Bakken, L.R., Yavitt, J.B., Shapleigh, J.P., 2016. Modularity of 553 nitrogen-oxide reducing soil bacteria: linking phenotype to genotype. Environmental $554 \quad$ Microbiology xx, xxx-xxx. doi:10.1111/1462-2920.13250

555 Rosenblatt, A.E., Gold, A.J., Stolt, M.H., Groffman, P.M., Kellogg, D.Q., 2001. Identifying 556 riparian sinks for watershed nitrate using soil surveys. Journal of Environmental Quality $557 \quad 30,1596-1604$.

558 Roussel-Delif, L., Tarnawski, S., Hamelin, J., Philippot, L., Aragno, M., Fromin, N., 2005.

$559 \quad$ Frequency and diversity of nitrate reductase genes among nitrate-dissimilating $560 \quad$ Pseudomonas in the rhizosphere of perennial grasses grown in field conditions. Microbial $561 \quad$ Ecology 49, 63-72. 
562 Russow, R., Stange, C.F., Neue, H.U., 2009. Role of nitrite and nitric oxide in the processes of nitrification and denitrification in soil: Results from ${ }^{15} \mathrm{~N}$ tracer experiments. Soil Biology \& Biochemistry 41, 785-795.

Schlesinger, W.H., 2009. On the fate of anthropogenic nitrogen. Proceedings of the National Academy of Sciences of the United States of America 106, 203-208.

Sears, H.J., Sawers, G., Berks, B.C., Ferguson, S.J., Richardson, D.J., 2000. Control of periplasmic nitrate reductase gene expression (napEDABC) from Paracoccus pantotrophus in response to oxygen and carbon substrates. Microbiology 146, $2977-$ 2985.

Shapleigh, J.P., 2012. The denitrifying prokaryotes, in: Rosenberg, E., Stackebrandt, E.,

Shapleigh, J.P., 2011. Oxygen control of nitrogen oxide respiration, focusing on alphaproteobacteria. Biochemical Society Transactions 39, 179-183.

Smith, M.S., Tiedje, J.M., 1979. Phases of denitrification following oxygen depletion in soil. Soil Biology \& Biochemistry 11, 261-267.

Stuven, R., Vollmer, M., Bock, E., 1992. The impact of organic matter on nitric oxide formation by Nitrosomonas europaea. Archives of Microbiology 158, 439-443.

Su, H., Cheng, Y., Oswald, R., Behrendt, T., Trebs, I., Meixner, F.X., Andreae, M.O., Cheng, P., Zhang, Y., Poschl, U., 2011. Soil nitrite as a source of atmospheric HONO and OH radicals. Science 333, 1616-1618.

Thorn, K.A., Mikita, M.A., 2000. Nitrite fixation by humic substances: Nitrogen-15 nuclear magnetic resonance evidence for potential intermediates in chemodenitrification. Soil Science Society of America Journal 64, 568-582. 
585 Vega-Jarquin, C., Valenzuela-Encinas, C., Neria-Gonzalez, I., Alcantara-Hernandez, R.J.,

586 Hernandez-Santiago, M.A., Luna-Guido, M.L., Marsch, R., Dendooven, L., 2008. Is

587 nitrate reduction to nitrite possible in glucose-amended alkaline saline soil under aerobic

$588 \quad$ conditions? Soil Biology \& Biochemistry 40, 2796-2802.

589 Watmough, N.J., Butland, G., Cheesman, M.R., Moir, J.W.B., Richardson, D.J., Spiro, S., 1999.

590 Nitric oxide in bacteria: synthesis and consumption. Biochimica et Biophysica Acta

$591 \quad$ (BBA) - Bioenergetics 1411, 456-474.

592

593 
595 Table 1

596 Sites from which soil was collected for ANR assay and bacterial isolation. Soil $\mathrm{pH}$ and soil

597 moisture were measured on the day of soil collection.

598

$599 \quad$ Site name

$\mathrm{pH}$

Soil moist.

Vegetation/

600

$(\%)$

Soil classification

601

McGowan agriculture

4.89

29

Corn /

602

Mesic Glossoboric Hapludalf

603 McGowan forest

Mixed hardwood forest /

604

Mesic Glossoboric Hapludalf

605 Smith agriculture

4.55

18

Corn /

606

Mesic Psammentic Hapludalf

607 Smith forest

Hardwood-Hemlock forest /

608

Mesic Psammentic Hapludalf

609 Hubbard Brook forest

3.76

52

Northern hardwood forest /

610

Typic Haplorthod

611 Stewart wetland pit

Red maple swamp /

612 hummock

4.05

35

Mesic Fluvaquentic Endoaquept

613 Sapsucker wetland pit

3.85

68

Maple-Alder-Hemlock swamp /

614 hummock

3.08

48

Mesic Mollic Endoaquept

615

616 
618 Table 2

619 Quantitative RT-qPCR of each dissimilatory nitrate reductase from the six genome sequenced

620 isolates. Values are mean + S.D. Copy numbers are given per $\mu$ g total RNA over five growth

621 conditions $^{\mathrm{a}}$ and each gene was run in triplicate.

622

623

Isolate 21

Isolate 26

624 Growth conditions

narI narII nap

625

AE_LowOD

$0.1 \pm 0.04$

$0.02 \pm 0.02$

$0.8 \pm 0.2$

626

AE_LowOD_NO3

$0.04 \pm 0.01$

$0.02 \pm 0.01$

$1.0 \pm 0.2$

627 AE_HighOD

$0.1 \pm 0.01$

$0.1 \pm 0.02$

$4.6 \pm 0.2$

628

AE_HighOD_NO 3

$0.3 \pm 0.03$

$4.5 \pm 1.0$

$5.7 \pm 0.4$

629 AN_HighOD_NO $\mathrm{NO}_{3}$

$0.1 \pm 0.01$

$24 \pm 4.0$

$3.0 \pm 0.3$

630

Isolate 2

632

Growth conditions

nar

nap

nar

nap

AE_LowOD

$0.6+0.2$

$2.6+0.4$

$0.1+0.05$

$0.03+0.01$

634 AE_LowOD_NO 3

$42+2.1$

$7.4+1.4$

$0.3+0.03$

$0.03+0.01$

635 AE_HighOD

$6.6+1.9$

$8.9+0.6$

$0.4+0.1$

$0.2+0.01$

636

AE_HighOD_NO 3

$57+21$

$27+9.2$

$1.0+0.1$

$0.3+0.04$

637 AN_HighOD_NO

N/A

N/A

N/A

N/A

638

639 
641 Growth conditions nar nar

$\begin{array}{llll}642 & \text { AE_LowOD } & 0.3+0.04 & 0.05+0.008 \\ 643 & \text { AE_LowOD_NO3 } & 0.3+0.06 & 0.05+0.008 \\ 644 & \text { AE_HighOD } & 1.9+0.16 & 0.08+0.01 \\ 645 & \text { AE_HighOD_NO3 } & 25+2.0 & 0.1+0.01 \\ 646 & \text { AN_HighOD_NO } 3 & \text { N/A } & \text { N/A }\end{array}$

647

$648{ }^{\mathrm{a}}$ The five growth conditions were: 1) AE_LowOD = Aerobic, low $\mathrm{OD}_{600}(<0.4)$, no $\left.\mathrm{NO}_{3} ; 2\right)$

649 AE_LowOD_NO $3=$ Aerobic low $\mathrm{OD}, 10 \mathrm{mM} \mathrm{KNO}$; ; no nitrite production detected; 3)

650 AE_HighOD $=$ Aerobic, high $\mathrm{OD}_{600}(>0.8)$, no NO $\left.3 ; 4\right) \mathrm{AE} \_H i g h O D \_N O_{3}=$ Aerobic, high $\mathrm{OD}$,

$65110 \mathrm{mM} \mathrm{KNO}_{3}$, nitrite detected; and 5) AN_HighOD_NO $3=$ Anaerobic, high $\mathrm{OD}_{600}(>0.8), 10$

$652 \mathrm{mM} \mathrm{KNO}_{3}$, no nitrite detected.

653

654

655 


\section{Figure captions}

661 Fig. 1. ANR activity in selected soils from the Northeast US. Average nitrite accumulation of 662 soils incubated in triplicate in different medium after five hours of incubation. Soils were 663 incubated in the following medium: 1) deionized water (W), 2) deionized water with $0.03 \mathrm{mg} \mathrm{N}$ -

$664 \mathrm{KNO}_{3} \mathrm{~g}^{-1}$ fresh-weight soil (W+N), 3) Sistrom's medium (SIS); 4) SIS plus 0.03 mg N-KNO $3 \mathrm{~g}^{-1}$ 665 fresh-weight soil (SIS+N); 5) SIS+N and $300 \mathrm{mM}$ dicyandiamide (DCD) (SIS+N+DCD), and 6)

$666 \mathrm{SIS}+\mathrm{N}$ and $113 \mathrm{mM}$ ammonium sulfate $\left(\mathrm{SIS}+\mathrm{N}+\mathrm{NH}_{4}\right)$. The last two medium are not shown as

667 they were not significantly different in nitrite accumulation compared to the SIS+N treatment.

668 The nine sites are as followed: McGowan Farm agricultural field (MA); McGowan Farm forest 669 (MF); Smith Woods agricultural field (SA); Smith Woods forest (SF); Hubbard Brook

670 Experimental Forest (HBEF); Stewart Park pits (SPP); Stewart Park hummocks (SPH);

671 Sapsucker Woods pits (SWP); and Sapsucker Woods hummocks (SWH).

672

673 Fig. 2. Oxygen concentration and nitrite measurements in six isolates. $\left[\mathrm{O}_{2}\right]$ in the liquid $(\%$ of 674 ambient, assuming $100 \%$ at first measurement) and specific net rate of $\mathrm{NO}_{2}^{-}$accumulation ( $V$ NO2-

$675 \mu \mathrm{mol} \mathrm{mg} \mathrm{mo} \mathrm{h}^{-1}$ ) in isolates $2,5,16,21,26$ and 28 in Sistrom's medium with 1 or $2 \mathrm{mM}$

676 (isolate 28 only) initial $\mathrm{NO}_{3}{ }^{-}$under initial atmospheric conditions $\left(21 \%\left[\mathrm{O}_{2}\right]\right) .1 \mathrm{mM}$ initial $\mathrm{NO}_{3}{ }^{-}$

677 equals $50 \mu \mathrm{mol} \mathrm{NO}{ }^{-}-\mathrm{N}$, and thus there is a potential accumulation of $50 \mu \mathrm{mol} \mathrm{NO} 2^{-}-\mathrm{N}^{2}$ vial ${ }^{-1}$. The 678 decline in oxygen is due to respiration and dilution by sampling. $\left[\mathrm{O}_{2}\right]$ is given as estimated 
679 average values for each mid-time increment of nitrite measurements. Specific net rates of $\mathrm{NO}_{2}^{-}$

680 production were estimated based on inferred dry mass (mg) per vial for each mid-time increment

681 of nitrite measurements, assuming a conversion factor of $0.4 \mathrm{mg} \mathrm{ml}^{-1} \mathrm{OD}_{600}{ }^{-1}$. Isolates 5,16 and

68228 reduced nearly all the available $\mathrm{NO}_{3}{ }^{-}$to $\mathrm{NO}_{2}{ }^{-}$, isolates 21 and 26 reduced nitrite further to $\mathrm{N}_{2}$

683 (not shown), and in the isolate 2 cultures, approximately $16 \%$ of the available $\mathrm{NO}_{3}{ }^{-}$was

684 recovered as $\mathrm{NO}_{2}{ }^{-}$at the end of the experiment. Solid black line and open squares: $\left[\mathrm{O}_{2}\right](\%$ of

685 ambient); dashed line, no symbol: $\mathrm{NO}_{2}^{-} \mu \mathrm{mol}$ vial ${ }^{-1}$; grey diamonds: $v_{\mathrm{NO}}-\left(\mu \mathrm{mol} \mathrm{mg}^{-1} \mathrm{dw} \mathrm{h}^{-1}\right)$. 
Fig. 1

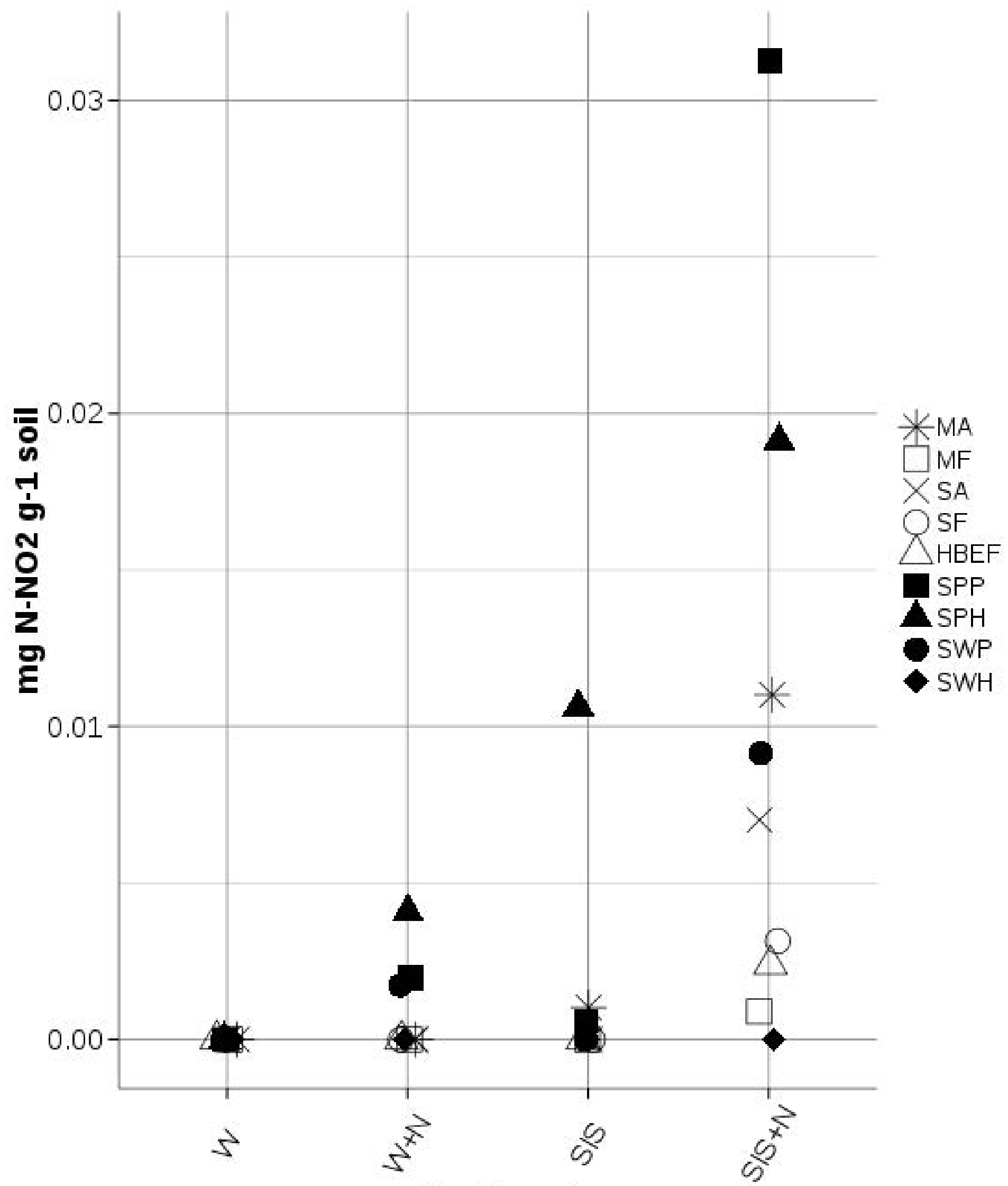

Treatment 
Fig. 2
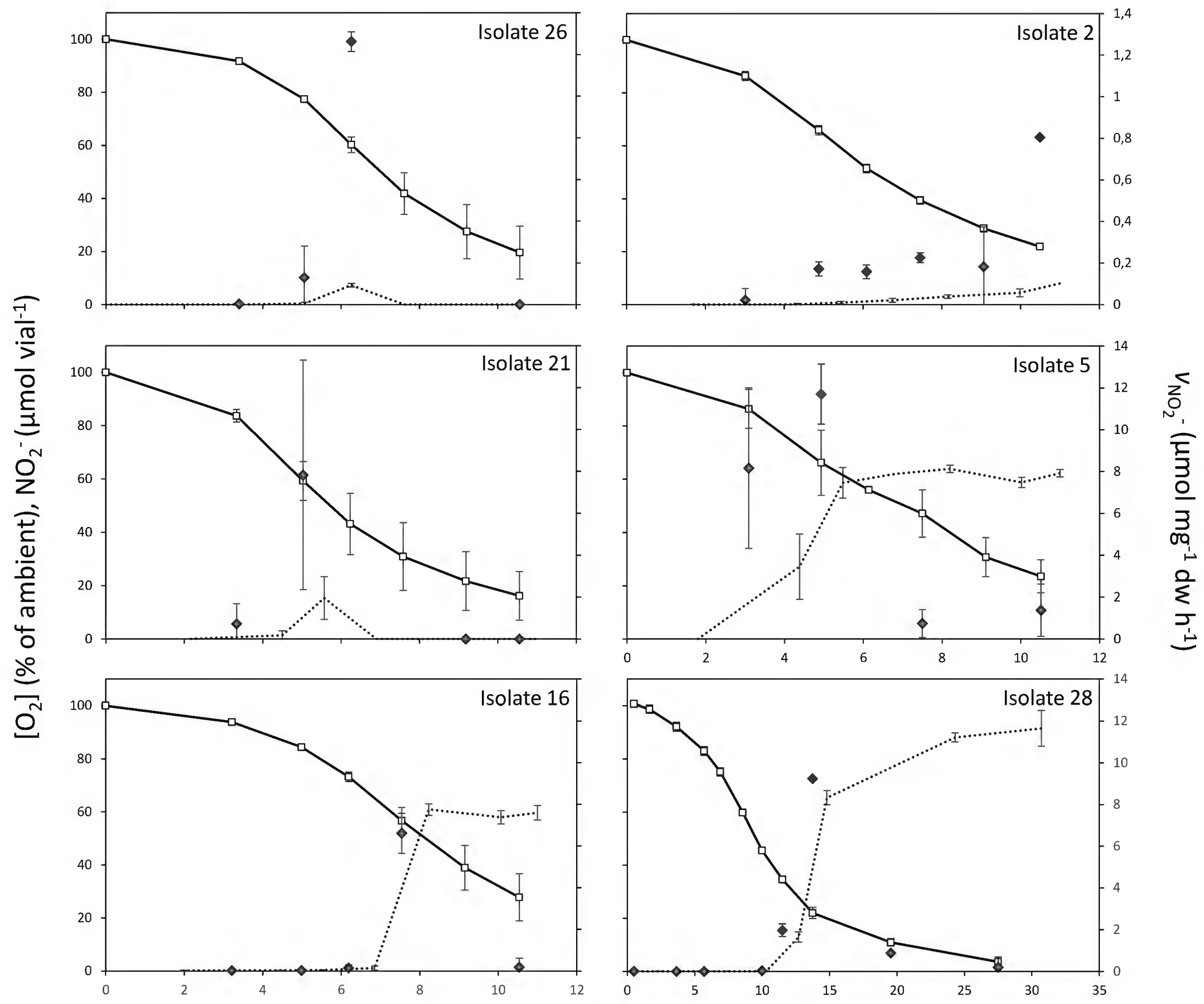

Time (h) 